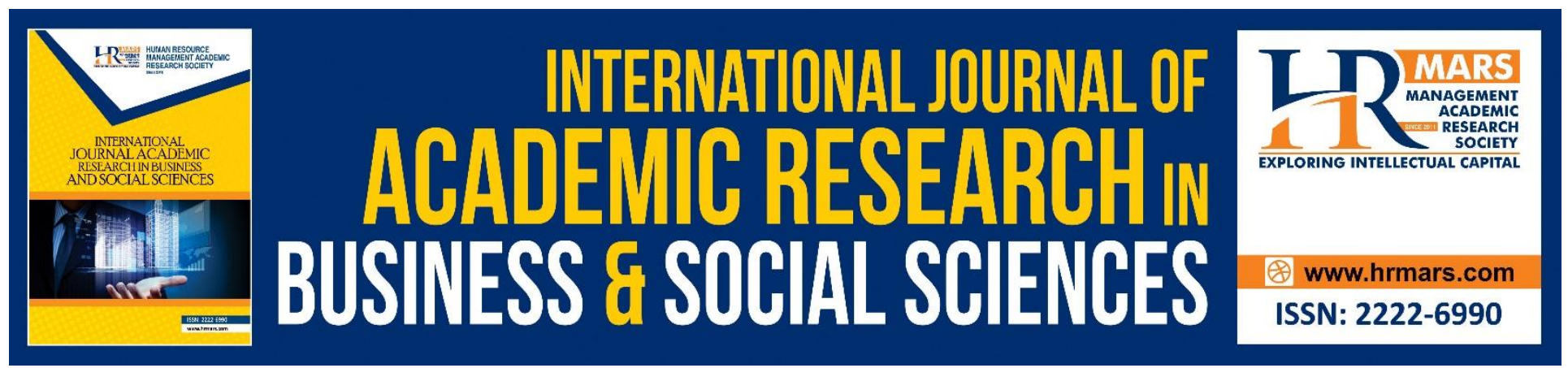

\title{
The Influence of Leadership by Public University Students to the Development of Citizenship in Malaysia
}

Abdullah Ibrahim, Wan Khairul Aiman Wan Mokhtar

To Link this Article: http://dx.doi.org/10.6007/IJARBSS/v8-i11/4708

DOI: $10.6007 /$ IJARBSS/v8-i11/4708

Received: 26 Oct 2018, Revised: 12 Nov 2018, Accepted: 26 Oct 2018

Published Online: 27 Nov 2018

In-Text Citation: (Ibrahim \& Mokhtar, 2018)

To Cite this Article: Ibrahim, A., \& Mokhtar, W. K. A. W. (2018). The Influence of Leadership by Public University Students to the Development of Citizenship in Malaysia. International Journal of Academic Research in Business and Social Sciences, 8(11), 338-347.

Copyright: (C) 2018 The Author(s)

Published by Human Resource Management Academic Research Society (www.hrmars.com)

This article is published under the Creative Commons Attribution (CC BY 4.0) license. Anyone may reproduce, distribute, translate and create derivative works of this article (for both commercial and non-commercial purposes), subject to full attribution to the original publication and authors. The full terms of this license may be seen

at: http://creativecommons.org/licences/by/4.0/legalcode

Vol. 8, No. 11, 2018, Pg. 338 - 347

http://hrmars.com/index.php/pages/detail/IJARBSS

JOURNAL HOMEPAGE

Full Terms \& Conditions of access and use can be found at http://hrmars.com/index.php/pages/detail/publication-ethics 


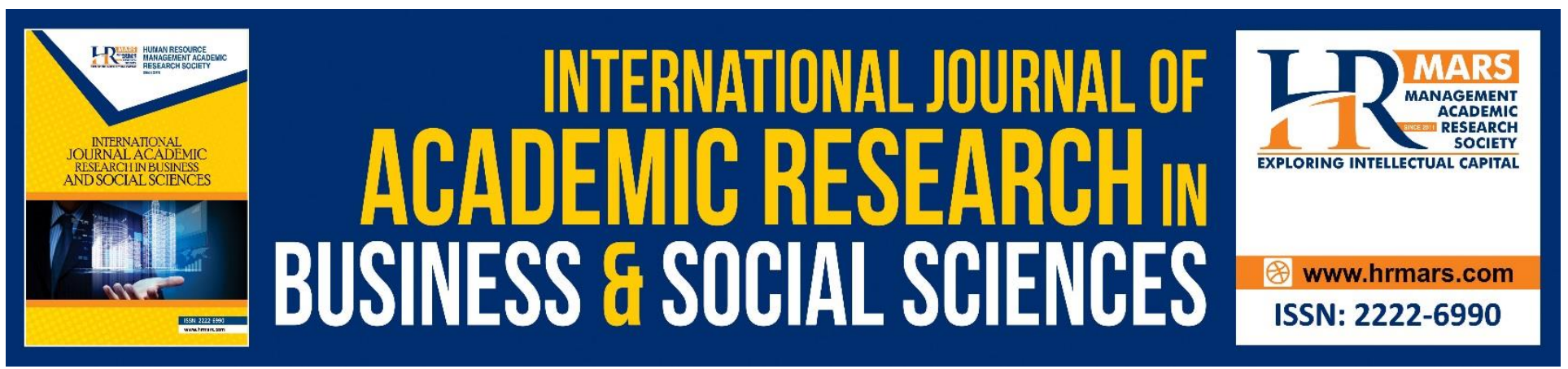

\title{
The Influence of Leadership by Public University Students to the Development of Citizenship in Malaysia
}

\author{
Abdullah Ibrahim \\ Faculty of General Studies and Advance Education (FUPL), Universiti Sultan Zainal Abidin (UniSZA), \\ Kampus Gong Badak, 21300 Kuala Nerus, Terengganu, Malaysia \\ Wan Khairul Aiman Wan Mokhtar \\ Faculty of General Studies and Advance Education (FUPL), Universiti Sultan Zainal Abidin (UniSZA), \\ Kampus Gong Badak, 21300 Kuala Nerus, Terengganu, Malaysia
}

\section{ABSTRACT}

As envisioned in Vision 2020, the progress and development depending on the succeed of a leader in maintaining the unity and sovereignty of the country continuously with cohesive step upon the Federal Constitution 1948 and the Principles of Rukun. Citizenship development and democratization of education is very important in ensuring the harmony and peace of a country. This process must take place properly for the benefit of all citizens to improve the country's progress in the future. Furthermore the undergraduates is the vanguard of countries that are expected to take on trust the leadership in the future. Students play an important role as a national leader and must have a level of understanding an appreciation of democratization and obligation as citizen of Malaysia. In particular level, this study is focusing on the influence of student leadership towards development of citizenship and democratization of education among students of public university of Malaysia. The cross-sectional survey method id applied in the process of collecting data which involve Student Leadership questionnaire which is formed by Kouzes \& Posner in the year of 2007, the Development of Citizenship questionnaire formed by Musil in the year of 2003 and the Democratization Education questionnaire by Evans \& Rose in 2007. 326 of students leader in the public university in Peninsula Malaysia were involved as the respondents in this research. The finding shows that there is $77.2 \%$ of the leadership practice of the Development of Citizenship and 39.6\% towards the Democratization Education. The Development of Citizenship proved to act as mediator in the relationship between student leadership and democratization education. This research can be used by the nation leaders, university administration and the department of education as guidance in valuing the aspect of leadership of the nation leaders apprentice. Besides, this research can be used as a basic reference 
INTERNATIONAL JOURNAL OF ACADEMIC RESEARCH IN BUSINESS AND SOCIAL SCIENCES

Vol. 8, No. 11, Nov, 2018, E-ISSN: 2222-6990 C 2018 HRMARS

to increase various knowledge regarding leadership management based on the citizenship development and the democratization education in forming the identity of the leaders.

Keywords: Student Leadership, Citizenship Development, Nationality Introduction

\section{INTRODUCTION}

Malaysia is a multi-racial and sovereign country which has achieved 57 years of independence. As a Malaysian who loves his country, it is vital that the citizens understands, appreciate and explore the contents of this country from pre-independence up until today (Ahmad,2005: Aquino \& Bommer, 2003). The effort to nurture and cultivate the nation of Malaysia to become superior, to strengthen the bond of unity and to create the spirit of patriotism and the love of the nation requires a proper understanding of the background of the formation of Malaysia and its development (Manaf, 2003: Barbuto \& Wheeler, 2006).

Hence every citizen must gain the basic knowledge of this beloved nation from the perspective of history up until the developments present which was gradually created through the independence of the country. This knowledge is especially important in the government's efforts to introduce policies which involves the integration of all citizens such as succeeding the Wawasan 2020 and the 1 Malaysia concept which leads to the developed nation's goals in accordance with its own reference by 2020 . Hence, nation-building is the ultimate goal of political development, which is a territory that has a border, government or government and citizen or nation.

Nation-building can be achieved through many forms of approach which includes the application of public policy formulated by the government and nurturing citizenship values through the nation's rituals and symbols the national anthem, the national flag and the celebration of independence day (Amri, 2014; Barling, Slater \& Kellow, 2000).

It is not an easy effort to develop a nation country due to various factors which must be taken into consideration. Among the factors which needs to be taken into account are the aspects of colonization, ethnic diversity, regional affiliation and government affiliation, the existence of political parties, parliaments, national constitutions and elections which are important components or criteria for determining the spirit of citizenship and democratization in Malaysia which must be continuously nourished (Ramlah Adam, 2014; Cavin \& McCuddy Michael, 2009: Chamil Wariya, 2001).

\section{ISSUES}

According Azizah Nordin (1991) and Abdul Salam Muhamad Shukri (2014) the young generation of Malaysia who are also the future leaders are faced with moral crisis and loss of citizenship virtues which are the foundation of a nation's identity. Illegal racing and drug addiction are becoming a major threat to the nation's future. The youngsters are prone to be involved in activities which brings no benefit such as illegal racing influenced by peers due to achieving pleasure, achieving popularity, weak family institution, mutual freedom of youngsters working and studying apart from home, cheap cost of such activity, mere knowledge of the law and an inadequate education on moral and religion (PDRM Dungun, 2008; Manaf, 2003; Sarwar, 2010). 
INTERNATIONAL JOURNAL OF ACADEMIC RESEARCH IN BUSINESS AND SOCIAL SCIENCES Vol. 8, No. 11, Nov, 2018, E-ISSN: 2222-6990 (C) 2018 HRMARS

According to statistics from police hauls, $85 \%$ of the offenders involved in illegal racing are between the ages of 16-21. Many of them are students, unemployed, freelancers and kiln workers. In terms of race, Malay $77.5 \%$, Chinese $13.3 \%$, Indian $9 \%$ and others $0.2 \%$. In the outcome of the haul of illegal racing, it is discovered that only $5 \%$ of the activity includes betting (PDRM Dungun, 2008). If this phenomenon is not curbed, it will erase the characteristics of leadership that are supposed to be instilled in future leaders.

This situation is a threat to Malaysia whose vision is to become a developed country (Mohamad, 1999; Ismail, Daud \& Don, 2006; Abdullah, 2009). It is found that the youths are facing a bleak spirit of citizenship and leadership values because they engage in activities that are unprofitable and detrimental to the future of the nation (Don, 2007; Abdullah, 2009; Sekaran, 2000).

Among the incidents and violent acts of the illegal racing gang which are seen as losing their identity and the spirit of citizenship is the attack at the Kubang Semang Bukit Mertajam Police Station in Seberang Prai. The attack broke out due to their friends who are a 19 and 20-year-old polytechnic student, was arrested for being involved in the illegal race (Utusan Malaysia, 26 ${ }^{\text {th }}$ August 2008; Baharudin, 2012; Kauzes \& Posner 2008). In a separate incident, an officer from Jabatan Pengangkutan Jalan was seriously injured after being hit by a 'Mat Rempit' who crashed a road block at Jalan Sultan Idris Shah 9 (Utusan Malaysia, 20 th October 2007; Halim, 2010).

These incidents clearly show that after 57 years of independence, Malaysians have lessened the values of citizenship and democratization system. Hence, a study should be conducted to obtain the latest inputs on factors relating to the low values of the citizenship of the young generation in Malaysia as they are the future leaders of the country. If they do not respect and support the rule of law, who else can be expected to take care of the country (Yatim, 2014; Halim, 2010; Kouzes \& Posner, 2008).

According Ku Hasnan Ku Halim (2013) and Saifudin Abdullah (2010) the main purpose of this research is to examine the influence of student leadership on the development of citizenship and democratization education among Public University students in Malaysia. The student-led leadership focuses on the Student Leadership Behavior model (Kouzes \& Posner, 2007; Musial, 2003; Saifudin Abdullah ,2009) namely leadership skills as a model, an inspirational leader, a visionary, an initiator, a collaborator and a motivational booster. Citizenship Development (Musil, 2005; Mayer, 2000; Hafizzudin, 2013) includes aspects of social responsibility, national development identity and citizen's obedience to the country, while democratization education is studied based on the understanding of democratization, political freedom, committed to the democratic system in the context of perception of the parliamentary system.

The institutions selected for this study is the Public University institution in the east zone of Peninsular Malaysia which are in the states of Kelantan, Terengganu, Pahang as well as the northern zone which involves Perlis, Kedah and Perak and the central zone involving Melaka and Negeri Sembilan (Morrison, 2001; Bakar,1973; Hafizzudin,2013). 
INTERNATIONAL JOURNAL OF ACADEMIC RESEARCH IN BUSINESS AND SOCIAL SCIENCES

Vol. 8, No. 11, Nov, 2018, E-ISSN: 2222-6990 (C) 2018 HRMARS

\section{METHODOLOGY}

This study is in the form of a survey which involves data collection for the purpose of identifying the influence of student leadership and the development of citizenship towards democratization in Malaysia. According to Krejic \& Morgan (1970) and Creswell \& Clark (2007), it seeks to capture some of the population's views being studied about issues or problems, observing variables and examining the relationship between the variables. Survey studies are used to identify trends in attitude and behavior, views and characters of a population (Creswell \& Clark, 2007; Krejic \& Morgan, 1970).

This study uses quantitative research methods. According to Cohen et al., (2000) and Creswell \& Clark (2007), if the study involves many respondents, quantitative methods are appropriate. The advantages of this design is it allows a lot of information to be collected at a time, economical and easy to handle (Creswell \& Clark, 2007). Additionally, the use of questionnaires to cover a large sample with low costs leads to a more detailed comparison of the study as well as a higher level of objectivity (Krejic \& Morgan, 1970; Sekaran \& Bougie, 2009).

Research is conducted as is the existing situation without any manipulation of the subject. The return period of the questionnaire from the subject is limited to one month. Remarks are not made on the subject if the resettlement rate of the questionnaire exceeds $60 \%$ as the sample of the study exceeding 200 persons is considered acceptable for the study without affecting the results of the study (McMillan, 2004; Krejic \& Morgan, 1970).

The large group of targets used in the study and generalized based on the selected sample is called a population (Krejic \& Morgan, 1970; Johnson, \& Christensen, 2004). The sample in the research refers to any group or small group or subset that represents the population and the information obtained can be used to make generalizations for the population (Chefler, 1988; Wallen \& Fraenkel, 1996; Cohen et al., 2000; Gorard, 2001).

The population of this study is the ranks of student leaders currently holding positions in Majlis Perwakilan Pelajar (MPP) responsible towards organizations in a public university and involved in general activities, co-curriculum, boarding house and association leaders. They are selected through the democracy system in the university among students who are not selected by the university management. The sample size of the population was selected based on recommendations by Krejic \& Morgan (1970) and McMillan (2004).

\section{DISCUSSION}

Overall, all dimensions of student leaders are found to have a positive and significant relationship with the dimensions of citizenship. The findings of the study have shown that student leadership dimensions of inspirational source leaders, emerging new ideas, and collaborators have a significant positive relationship with moderate strength with the dimension of citizenship (Saifudin, 2009; Nordin, 1991; Abdul Razaq Ahmad, 2013). However, student leadership dimensions of model leaders have been found to have a significant positive relationship with strong strength while student 
INTERNATIONAL JOURNAL OF ACADEMIC RESEARCH IN BUSINESS AND SOCIAL SCIENCES Vol. 8, No. 11, Nov, 2018, E-ISSN: 2222-6990 C 2018 HRMARS

leadership motivational motivation dimensions have positive significance but with weak strength with citizenship dimension (Manaf, 2003; Barbuto \& Wheeler, 2006).

The findings of this study are consistent with the study of Anthony Alexander (2012) and Ahmad (2005), citizenship education is not the sole responsibility of government but also the responsibility of all components of society, race, and country. In addition, to be able to understand and exercise the rights and duties in a manner that is polite, honest, and democratic as well as sincere as an educated citizen in his life as a responsible citizen (Nordin, 1991; Barling, Slater \& Kelloway, 2000). This clearly demonstrates that leadership values are largely related to citizenship education. It meets the study which shows that the level of formal education of citizenship has a direct and indirect positive impact on democratic attitudes (Evans \& Rose 2007; Hoskins et al 2008; Mattes \& Mughogho 2010).

Citizenship Education is one of the efforts to revive the spirit of nationalism in the younger generation, especially the students. It is important to deal with the influence of globalization and to strengthen the value of consciousness in defending the state (Ismail, Daud \& Don,2006; Aquino \& Boomer, 2003). Being one of the citizens, we must understand the rights and obligations, and the love for the country. We recognize that the era of circulation has made our lives and responsibilities as a citizen at this time is more challenging than the past (Manaf, 2003; Barbuto \& Wheeler, 2006). Therefore, the role of students acting as model leaders, inspirational sources, and triggering new ideas greatly influences the citizenship of the citizenship (Barling, Slater \& Kelloway, 2000; Wariya, 2010).

The ultimate aim of citizenship education is to realize the insights and awareness of citizenship values, patriotic attitudes and values nurtured from the nation's culture, the archipelagic insights, as well as national resistance in the student as a candidate for the nation's hopeful scholars. As a candidate of scholars, students are expected to master the various educational fields according to their interests and abilities that can later be used as a means of nation building. In addition to having a scientific basis, a student is required to have a good personality and a nationality vision (Abdullah, 2009; Barnes \& Morgeson, 2007; Wariya, 2010).

This is supported by Chaudhary Imran Sarwar (2013) and Barbuto \& Wheeler (2006) stating that students are a key element in generating future world leaders. Hence, moral and academic education capable of forming personality and leadership qualities is necessary to ensure students are prepared to deal with responsibility as a national leader. The importance of student leadership influences also impacts the development of citizenship of university students. This is further reinforced with the results of the study showing the contribution of these aspects to the development of citizenship of public university students in Malaysia Abdullah, 2009; Cavin McCuddy Michael, 2009; Wariya, 2010). The results of the analysis show that the dimensions of student leadership studies have contributed to the improvement of citizenship development among public university students in Malaysia. In addition, the findings also show dimensions of student leadership which has a 
INTERNATIONAL JOURNAL OF ACADEMIC RESEARCH IN BUSINESS AND SOCIAL SCIENCES

Vol. 8, No. 11, Nov, 2018, E-ISSN: 2222-6990 (C) 2018 HRMARS

significant influence on dimensions of development of social responsibility citizenship, identity development, and obedience (Kouzes \& Posner, 2007; Halim, 2010; Alias, 2005).

\section{CONCLUSION}

The implementation of the study which is the basis of this study is that there is a very useful contribution to the field of leadership and management of the university, as well as various implications for the development of citizenship and democratization education of public university students in Malaysia (Morrison, 2001; Bakar, 1973; Hafizzudin, 2013). Overall, the results of this study have achieved the objectives and answered questions of the research.

The findings show that student leadership plays an important role in the development of citizenship and democratization education of public university students in Malaysia (Mayer,2000: Morrison,2001).

The importance of student leadership is seen in terms of its influence on student leaders who will be able to enhance citizenship development and further enhance the democratization education of public university students in Malaysia (Mattes, Davids \& Africa, 1999; Mayer, 2000; Yazid, 2011).

The aspects of student leadership influence on these dimensions of development of citizenship can be further enhanced through subscales in student leadership, gender, age, and occupational role of a family leader identified in the relevant variables (Morrison, 2001; Hafizzudin, 2013; Alias; Abdullah, 2009).

\section{ACKNOWLEDGEMENT}

This paper is founded on the research project of the Special Research Grant Scheme (SRGS)UniSZA/2017/SRGS/21. Special appreciation is owed to Ministry of Higher Education Malaysia (MOHE) and Universiti Sultan Zainal Abidin (UniSZA) for sponsoring and supporting this research.

\section{CORRESPONDING AUTHOR}

Wan Khairul Aiman bin Wan Mokhtar (Ph.D), Senior Lecturer, Faculty of General Studies and Advance Education (FUPL), Universiti Sultan Zainal Abidin (UniSZA), Kampus Gong Badak, 21300 Kuala Nerus. E-mail:wk_aiman@yahoo.com/wkhairulaiman@unisza.edu.my

\section{REFERENCES}

Ahmad, A. R. (2005). Mahasiswa Abad ke 21. Universiti Kebangsaan Malaysia, Selangor: Dewan Bahasa dan Pustaka.

Shukri, A.S.M. (2014). Konsep Tentang Perpaduan Nasional: Suatu Tinjauan Awal. Terengganu: Universiti Sultan Zainal Abidin.

Ismail, A., Daud, Y., \& Don, Y. (2006). Kepimpinan \& Pembangunan Pelajar Sekolah di Malaysia. Batu Caves: PTS Professional Publishing. 
INTERNATIONAL JOURNAL OF ACADEMIC RESEARCH IN BUSINESS AND SOCIAL SCIENCES

Vol. 8, No. 11, Nov, 2018, E-ISSN: 2222-6990 (C) 2018 HRMARS

Manaf, A.A (2003). Kemunculan Malaysia Moden. Kuala Lumpur: Universiti Sains Malaysia.

Nordin, A. (1991). Kokurikulum dan Sumbangannya Terhadap Perkembangan Diri Individu Secara Menyeluruh. Jurnal Pendidikan Guru. (7) : 33-42.

Aquino, K. \& Bommer, W.H. (2003). Preferential mistreatment: How Victim Status Moderates the relationship between organizational behavior and Workplace victimization. Organizational Science, 14 (4), 374-385.

Mohammad,B., Esa,A., Hashim,M.N., Hadi,M.Y.A., Hashim,J., \& Hussin,N.F (2008). Pendekatan Tauhid dalam kepimpinan pendidikan. Seminar Kebangsaan Pengurusan Pendidikan PKPGB. Johor: Universiti Tun Hussien Onn Malaysia.

Baker, T.L. (1994). Doing Social Research. 2nd Edition. New York : Mc Graw Hill Inc. Band Research, 42(2), 57-70.

Barbuto, I. E., \& Wheeler, D. W. (2006). Scale development and construct clarification of servant leadership. Group \& Organization Management, 31(3), 326.

Barling, J., Slater, F., \& Kelloway, E. (2000). Transformational leadership and emotional intelligence: An exploratory study. Leadership \& Organization Development Journal, 21(3), 157-161.

Barnes, C. M., \& Morgeson, F. P. (2007). Typical performance, maximal performance, and performance variability: Explaining our understanding of how organizations value performance. Human Performance, 20 (3), 259-274

Cavin, C., dan McCuddy Michael. (2009). The Demographic Context Of Servant Leadership. Journal Of Academy Of Business And Economics. 9 (2). 129-139.

Chamil, W. (2010). Malaysia : Asas Pembinaan Negara Bangsa Institusi Pemerintahan Lambang Kebangsaan (edisi kedua). Petaling Jaya. Media Global Matrix Sdn. Bhd.

Sarwar, C.I (2013). Future of Ethically Effective Leadership. Journal of Bussiness Ethics, 113, 81-89. doi: 10.1007/s10551-012-1283-9 9 (ADA) Connaughton.

Che Su, M., Maznah, A.H., \& Faizah, A. (2007). The relationship between workculture and organizational citizenship behavior among Malaysisa employees. Paper presented at The International Conference, Singapore Management University.

Abdullah, S. (2009). Kalau Saya Mahasiswa. Kuala Lumpur: Institut Terjemahan Negara. 
INTERNATIONAL JOURNAL OF ACADEMIC RESEARCH IN BUSINESS AND SOCIAL SCIENCES

Vol. 8, No. 11, Nov, 2018, E-ISSN: 2222-6990 (C) 2018 HRMARS

Abdullah, S. (2009). Politik Baru, Mematangkan Demokrasi Malaysia. Kuala Lumpur : Institut Terjemahan Negara.

Abdullah, S. (2010). Benarkan Mahasiswa Berpolitik. Kuala Lumpur: Institut Terjemahan Negara.

Sekaran, U. \& Bougie, R. (2009). Research Method For Business; A Skill Building Approach (5th. ed.). New York: John Wiley \& Son Inc.

Sekaran, U. (2000). Research Method For Business; A Skill Building Approach (2nd ed.). New York: John Wiley \& Son Inc.

Shahmir, B., House, R., \& Arthur, M. (1993). The Motivational Effects Of Charismatic Leadership: A Self-Concept Based Theory. Organizational Science, 4, 1-17.

Baharuddin, S.A (2012). Modul Hubungan Etnik, Kuala Lumpur: Solid Press Sdn. Bhd.

Musil, C. M. (2003). Educating For Citizenship. AAC\&U peer review, 4-8.

Mattes, R. \& Mughogho, D. (2010). The Limited Impacts of Formal Education on Democratic Citizenship in Africa. HERANA Research Report. Cape Town: CHET. Diakses dari www.chet.org.za pada Mei 24, 2016

Kouzes, J. M., \& Posner, B. Z. (1995). The Leadership Challenge: How To Keep Getting Extraordinary Things Done In Organizations. San Francisco: Jossey-Bass.

Kouzes, J. M., \& Posner, B. Z. (2006). Student leadership practices inventory: Facilitator'sguide. San Francisco: Jossey-Bass Publishers.

Kouzes, J. M., \& Posner, B. Z. (2007). The Leadership Challenge (4th ed.). San Francisco:Jossey-Bass.

Kouzes, J. M., \& Posner, B. Z. (2008). The Student Leadership Challenge: Five Practices For Exemplary Leaders: San Francisco, CA, US: Jossey-Bass.

Krejcie, R. V., \& Morgan, D. W. (1970). Determining Sample Size For Research Activities. Educational Psychology Measurement, 3, 607- 610.

Halim, K.H.K. (2009). Darjat Tidak Datang Bergolek. Johor: Universiti Tun Hussien Onn Malaysia.

Halim,K.H.K. (2013). Bahtera Marhalah Bangsa. Johor: Universiti Tun Hussien Onn Malaysia.

Halim,K.H.K. (2010). Bumi Dipijak, Langit Dijunjung. Johor: Universiti Tun Hussien Onn Malaysia 
INTERNATIONAL JOURNAL OF ACADEMIC RESEARCH IN BUSINESS AND SOCIAL SCIENCES

Vol. 8, No. 11, Nov, 2018, E-ISSN: 2222-6990 (C) 2018 HRMARS

Alias, M. (2005). The Compatibility Of Literature Component Novels In Bahasa Melayu Curriculum.

Mathieu, J. E., \& Taylor, S. R. (2006). Clarifying Conditions And Decision Points For Meditational Type Inferences In Organizational Behaviour. Journal of Organizational Behavior, 27, 1031-1056.

Mattes, R. \& Mughogho, D. (2010). The Limited Impacts Of Formal Education On Democratic Citizenship In Africa. HERANA Research Report. Cape Town: CHET. Diakses dari www.chet.org.za pada Mei 24, 2016.

Mattes, R., Davids, Y. D., \& Africa, C., (1999). Views of Democracy in South Africa and The Region: Trends and Comparisons. South African Democracy Barometer. Cape Town.

Mayer J.D. (2000). Emotion, Intelligence, Emotional Intelligence. In J.P. Forgas (Ed.). The Handbook of affect and social cognition (pp. 410-431). Mahwah, NJ: Lawrence Erlbaum Associates, Inc.

Yazid, M.N. (2011). Percaturan Kuasa Dan Politik Pilihan Raya. Kuala Lumpur: Utusan Publications \& Distributors Sdn. Bhd.

Morrison, E. A. (2001). Exploring The Relationship Of Undergraduates' Self-Perceived Citizenship And Service Participation. Unpublished master's thesis, University of Maryland, College Park.

Hafizzudin, M. (2013). Ada Hikmah Di Sebalik Peristiwa Hitam Lahad Datu. Semangat Patriotism Kembang Mekar Di Kalangan Rakyat Malaysia.

Bakar, M.A. (1973). Mahasiswa Menggugat. Cetakan pertama. Penerbitan Pustaka, Kuala Lumpur. 